NASA/TM-2005-213805

\title{
Off-Design Performance Analysis of a Solid-Oxide Fuel Cell/Gas Turbine Hybrid for Auxiliary Aerospace Power
}

Joshua E. Freeh and Christopher J. Steffen, Jr.

Glenn Research Center, Cleveland, Ohio

Louis M. Larosiliere

General Electric Gas Turbines, Greenville, South Carolina 
Since its founding, NASA has been dedicated to the advancement of aeronautics and space science. The NASA Scientific and Technical Information (STI) Program Office plays a key part in helping NASA maintain this important role.

The NASA STI Program Office is operated by Langley Research Center, the Lead Center for NASA's scientific and technical information. The NASA STI Program Office provides access to the NASA STI Database, the largest collection of aeronautical and space science STI in the world. The Program Office is also NASA's institutional mechanism for disseminating the results of its research and development activities. These results are published by NASA in the NASA STI Report Series, which includes the following report types:

- $\quad$ TECHNICAL PUBLICATION. Reports of completed research or a major significant phase of research that present the results of NASA programs and include extensive data or theoretical analysis. Includes compilations of significant scientific and technical data and information deemed to be of continuing reference value. NASA's counterpart of peerreviewed formal professional papers but has less stringent limitations on manuscript length and extent of graphic presentations.

- TECHNICAL MEMORANDUM. Scientific and technical findings that are preliminary or of specialized interest, e.g., quick release reports, working papers, and bibliographies that contain minimal annotation. Does not contain extensive analysis.

- CONTRACTOR REPORT. Scientific and technical findings by NASA-sponsored contractors and grantees.
- CONFERENCE PUBLICATION. Collected papers from scientific and technical conferences, symposia, seminars, or other meetings sponsored or cosponsored by NASA.

- SPECIAL PUBLICATION. Scientific, technical, or historical information from NASA programs, projects, and missions, often concerned with subjects having substantial public interest.

- TECHNICAL TRANSLATION. Englishlanguage translations of foreign scientific and technical material pertinent to NASA's mission.

Specialized services that complement the STI Program Office's diverse offerings include creating custom thesauri, building customized databases, organizing and publishing research results ... even providing videos.

For more information about the NASA STI Program Office, see the following:

- Access the NASA STI Program Home Page at http://www.sti.nasa.gov

- E-mail your question via the Internet to help@sti.nasa.gov

- Fax your question to the NASA Access Help Desk at 301-621-0134

- Telephone the NASA Access Help Desk at 301-621-0390

- Write to:

NASA Access Help Desk

NASA Center for AeroSpace Information 7121 Standard Drive

Hanover, MD 21076 
NASA/TM-2005-213805

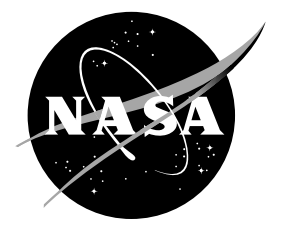

\section{Off-Design Performance Analysis of a Solid-Oxide Fuel Cell/Gas Turbine Hybrid for Auxiliary Aerospace Power}

Joshua E. Freeh and Christopher J. Steffen, Jr.

Glenn Research Center, Cleveland, Ohio

Louis M. Larosiliere

General Electric Gas Turbines, Greenville, South Carolina

Prepared for the

Third International Conference on Fuel Cell Science, Engineering, and Technology cosponsored by the ASME, ASME Nanotechnology Institute, Mechanical Engineering Magazine, RIT, NFCRC, Kettering University, SME, and Fuel Cell Markets Ypsilanti, Michigan, May 23-25, 2005

National Aeronautics and Space Administration

Glenn Research Center 


\section{Acknowledgments}

The authors would like to acknowledge Robert Tornabene and Xiao-yen Wang for their help with the heat exchanger modeling and the system mass estimation.

This work was sponsored by the Low Emissions Alternative

Power Project of the Vehicle Systems Program at the NASA Glenn Research Center.

Available from

NASA Center for Aerospace Information 7121 Standard Drive

Hanover, MD 21076
National Technical Information Service 5285 Port Royal Road Springfield, VA 22100 


\title{
Off-Design Performance Analysis of a Solid-Oxide Fuel Cell/Gas Turbine Hybrid for Auxiliary Aerospace Power
}

\author{
Joshua E. Freeh and Christopher J. Steffen, Jr. \\ National Aeronautics and Space Administration \\ Glenn Research Center \\ Cleveland, Ohio 44135 \\ Louis M. Larosiliere \\ General Electric Gas Turbines \\ Greenville, South Carolina 29602
}

\begin{abstract}
A solid-oxide fuel cell/gas turbine hybrid system for auxiliary aerospace power is analyzed using $0-\mathrm{D}$ and $1-\mathrm{D}$ system-level models. The system is designed to produce $440 \mathrm{~kW}$ of net electrical power, sized for a typical long-range 300-passenger civil airplane, at both sea level and cruise flight level $(12,500 \mathrm{~m})$. In addition, a part power level of $250 \mathrm{~kW}$ is analyzed at the cruise condition, a requirement of the operating power profile. The challenge of creating a balanced system for the three distinct conditions is presented, along with the compromises necessary for each case. A parametric analysis is described for the cruise part power operating point, in which the system efficiency is maximized by varying the air flow rate. The system is compared to an earlier version that was designed solely for cruise operation. The results show that it is necessary to size the turbomachinery, fuel cell, and heat exchangers at sea level full power rather than cruise full power. The resulting estimated mass of the system is $1912 \mathrm{~kg}$, which is significantly higher than the original cruise design point mass, $1396 \mathrm{~kg}$. The net thermal efficiencies with respect to the fuel LHV are calculated to be 42.4 percent at sea level full power, 72.6 percent at cruise full power, and 72.8 percent at cruise part power. The cruise conditions take advantage of precompressed air from the on-board Environmental Control System, which accounts for a portion of the unusually high thermal efficiency at those conditions. These results show that it is necessary to include several operating points in the overall assessment of an aircraft power system due to the variations throughout the operating profile.
\end{abstract}

\section{Introduction}

The aircraft auxiliary power unit (APU) typically provides the majority of electrical power for on-board systems when on ground. It also serves as a backup power source on portions of certain long-distance flights, known as Extended-Range TwinEngine Operations (ETOPS) (ref. 1). Current APUs are gas turbine-based systems that have not been the focus of emissions and noise reduction due to their relative small size and short usage time when compared to the propulsion gas turbines. As a result, for ground operations, they now produce as much as 20 percent of the aircraft $\mathrm{NO}_{\mathrm{x}}$ emissions and a significant amount of noise (ref. 2).

Future aircraft designs are projected to require a significant increase in auxiliary electrical loads due to increased application of electromechanical actuators, passenger services, and communications. The increase in power demand will be at least partly met by increasing the size of the APU and also migration to a full-time auxiliary power unit, where the unit is operational in-flight as well as on ground. The need for a cleaner and quieter system becomes more apparent with this scenario.

There are multiple solutions to this problem. One approach is to improve the existing gas turbine with a cleaner and quieter design. For example, the overall pressure ratio and turbine temperatures can be increased for both higher efficiency and higher specific power systems. Further, more innovative cycles involving heat exchangers similar to those proposed in this hybrid system may be used for higher efficiency. The comparative risk with these approaches is low since the gas turbine is well understood; however, there is a limited amount of improvement possible because issues such as rotational machinery tip clearances and turbine blade cooling become more of a challenge at these smaller sizes. Another solution is to produce more power from the existing starter/generators on each of the propulsion engines. These units are necessary for the startup of the main engines and produce power efficiently and with low mass. Drawbacks include the adverse effect on the propulsion engine efficiency and potential physical interference with the rotating machinery as the generator power and diameter both increase. In addition, redundancy requirements require a power production unit independent of the engines, especially for ETOPS (ref. 1). For terrestrial power needs, a simpler approach is being used at some airports where the aircraft receives electrical power from the airport power grid itself. This may be a very positive solution overall, but in-flight power requirements and redundancy issues still exist. Finally, quieter and cleaner technology can be used in place of the gas turbine APU, such as batteries and fuel cells. This approach is being examined by both government and industry, and is the subject of this paper.

Earlier efforts (refs. 2 to 4 ) have studied the feasibility of this idea from the overall aircraft perspective and at a systems design level. An initial requirement that guided this work is that only one fuel (jet fuel) is allowed due to near-term 
customer and operational restrictions. Jet fuel is a complex mixture of hydrocarbons and impurities such as sulfur-based species; reforming the fuel to an acceptable level for automotive-based PEM fuel cells will be very difficult within the mass and volume restrictions. The Solid Oxide Fuel Cell (SOFC) is more amenable to impurities and carbon monoxide even acts as a fuel and indirect additional source of hydrogen (through the water-gas-shift reaction). Therefore, the SOFC has been the baseline system for much of the early analysis. A SOFC-based system is much heavier than a gas turbine per unit power, however, and one way to counteract this is to take advantage of the potentially higher efficiency of the SOFC. When the fuel mass saved from the difference in efficiency is accounted for, the system compares favorably with a gas turbine system. Furthermore, an even higher efficiency can be achieved by incorporating a smaller gas turbine as a bottoming cycle to the SOFC. Results show that such a system may be feasible from a mass and volume perspective and the estimated emissions and noise benefits merit further consideration (refs. 2 to 4 ).

The above results have focused on the cruise portion of the aircraft mission; the next step is to analyze system performance at different points across the operating envelope. This paper extends the earlier analysis by including full power $(440 \mathrm{~kW})$ system performance for ground operations and part power $(250 \mathrm{~kW})$ operation at cruise. The power levels are typical of a 300 passenger commercial transport aircraft and are based on figure 1 (ref. 5), a projected power profile for each of the various mission segments. The $250 \mathrm{~kW}$ level is approximately the lowest operational requirement of the mission.

Analysis of both sea level and cruise conditions is required due to the corresponding ambient temperature and pressure change. Based on the 1976 International Standard Atmosphere, the temperature changes from $288 \mathrm{~K}$ at sea level to $216 \mathrm{~K}$ at $12,500 \mathrm{~m}(41,000 \mathrm{ft})$, a typical cruise altitude for a modern long-range civil transport. The corresponding pressure changes are even more dramatic, ranging from 1 to 0.178 bar at sea

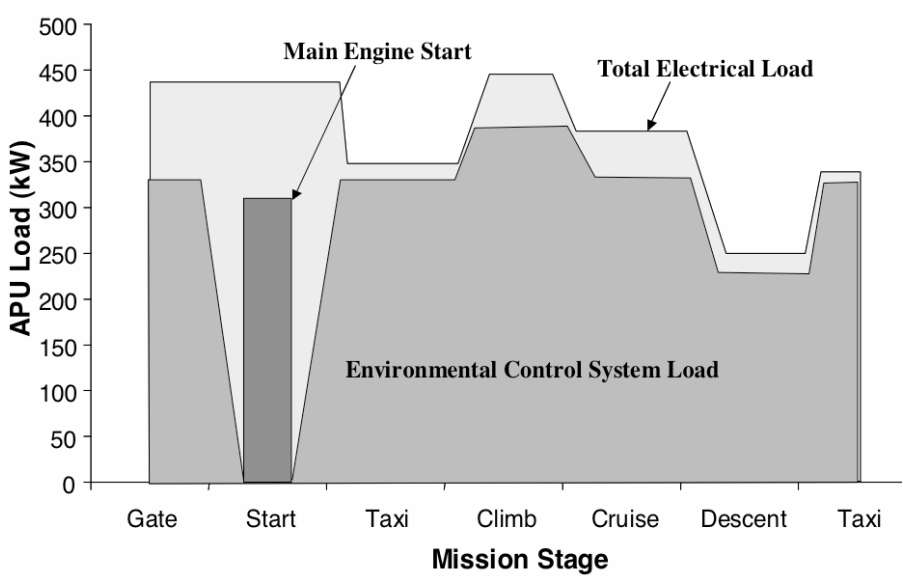

Figure 1.-Projected net electrical power requirements at various mission stages (from (ref. 5) with permission). level and cruise, respectively. The propulsion engines must perform throughout these variations and design compromises are made to ensure acceptable performance at all conditions. For the power system, similar compromises are required. However, this analysis uses the airplane cabin exhaust as its air source, greatly reducing the effect of the varying atmospheric pressure. For passenger comfort, the onboard Environmental Control System (ECS) regulates the temperature and pressure of the cabin to $293 \mathrm{~K}$ and 0.75 bar at cruise. Typically 50 percent of the air is recirculated while the remainder is sent overboard. The air sent overboard is sufficient for the SOFC/GT power system, and is therefore used throughout the mission. As a result, the power system inlet pressure variation is only from 1 to 0.75 bar, rather than 1 to 0.178 bar, simplifying the compressor design and boosting the system thermal efficiency at cruise. Accounting for the ECS compressor work, which requires a significant amount of power, is outside the scope of this current work since the ECS is used for both the fuel cell and gas turbine power units. A broader aircraft-level study that accounts for all power requirements and power production methods is justified for a more integrated overall power system.

Operating at different altitudes will also affect the system exhaust pressure. For this analysis, the exhaust pressure is the ambient pressure at all cases. The exhaust pressure governs the turbine expansion ratio and will therefore have a dramatic effect on this system performance. This effect will prove to be a major driver in this system design.

Terrestrial power production, another potential application for the SOFC/GT hybrids, must successfully operate at varying ambient and part-power conditions as well. Some research groups have begun to evaluate terrestrial-based hybrid systems at these conditions and have suggested control strategies based on the model results (ref. 6). Transient analyses of system startup, shutdown, and power load changes have also gained attention due to the many related challenges and applicability for all hybrid systems (refs. 7 to 9). All of these conditions may substantially affect the design of the system.

A final necessary note is that future SOFC technology is projected for this application and specifically for this analysis. A typical timeline for a new aircraft development, especially a large civil transport, is on the order of 10 to 20 years. Systems analyses such as the following are required at this early stage and projections for both technology and the application are a challenging part of the design process. SOFC and SOFC/GT hybrid technology have made progress over the past decades but further maturity is necessary before an application such as this is feasible. Systems studies may extrapolate the capability of a technology, but the studies also quantify the necessary gains that must be made for feasibility. A more thorough discussion for this application can be found in (ref. 3 ).

\section{Nomenclature}

$\begin{array}{ll}\text { ETOPS } & \text { Extended-Range Twin-Engine Operations } \\ \text { SOFC } & \text { Solid Oxide Fuel Cell } \\ \text { SOFC/GT } & \text { Solid Oxide Fuel Cell/Gas Turbine Hybrid }\end{array}$




\begin{tabular}{|c|c|}
\hline ECS & Environmental Control System \\
\hline ASR & Area Specific Resistance \\
\hline $\mathrm{O} / \mathrm{C}$ & Molar atomic oxygen-to-carbon ratio \\
\hline $\mathrm{H}_{2} \mathrm{O} / \mathrm{C}$ & Molar steam-to-carbon ratio \\
\hline $\mathrm{PR}_{\mathrm{tt}}$ & Total-total pressure ratio \\
\hline W & Flow rate, $\mathrm{kg} / \mathrm{s}$ \\
\hline $\mathrm{Wc}$ & Corrected flow, $\mathrm{kg} / \mathrm{s}, W c=W \frac{\sqrt{\theta}}{\delta}$ \\
\hline $\mathrm{Nc}$ & Corrected speed, $\mathrm{rpm}, \mathrm{Nc}=\frac{\mathrm{N}}{\sqrt{\theta}}$ \\
\hline$\theta$ & Temperature ratio, $\theta=\frac{\mathrm{T}}{\mathrm{T}_{\text {ref }}}$ \\
\hline$\delta$ & Pressure ratio, $\delta=\frac{\mathrm{P}}{\mathrm{P}_{\mathrm{ref}}}$ \\
\hline $\mathrm{T}$ & Temperature, $\mathrm{K}$ \\
\hline $\mathrm{P}$ & Pressure, psi \\
\hline $\mathrm{T}_{\mathrm{ref}}$ & Reference temperature, $273 \mathrm{~K}$ \\
\hline $\mathrm{P}_{\text {ref }}$ & Reference pressure, $14.696 \mathrm{psi}$ \\
\hline$\eta_{\mathrm{tt}}$ & Total-total adiabatic efficiency \\
\hline
\end{tabular}

\section{Model Description}

The hybrid configuration, presented in further detail in (refs. 3 and 4), is shown in figure 2. It is a bottoming cycle in which the remaining fuel from the exhaust of the SOFC system is burned in a small combustor to produce additional heat energy for two heat exchangers and the turbine. The turbine drives a compressor that compresses the air for both the fuel cell and reformer. Any residual turbine power is converted to electrical power using a generator. The reformer is based on partial-oxidation chemistry though some water is added to prevent coking. Both the compressor and turbine are singlestage radial designs. The fuel and water pumps are simple low pressure, low flow rate, liquid pumps whose required work is negligible compared to that of the gas compressor. The mass

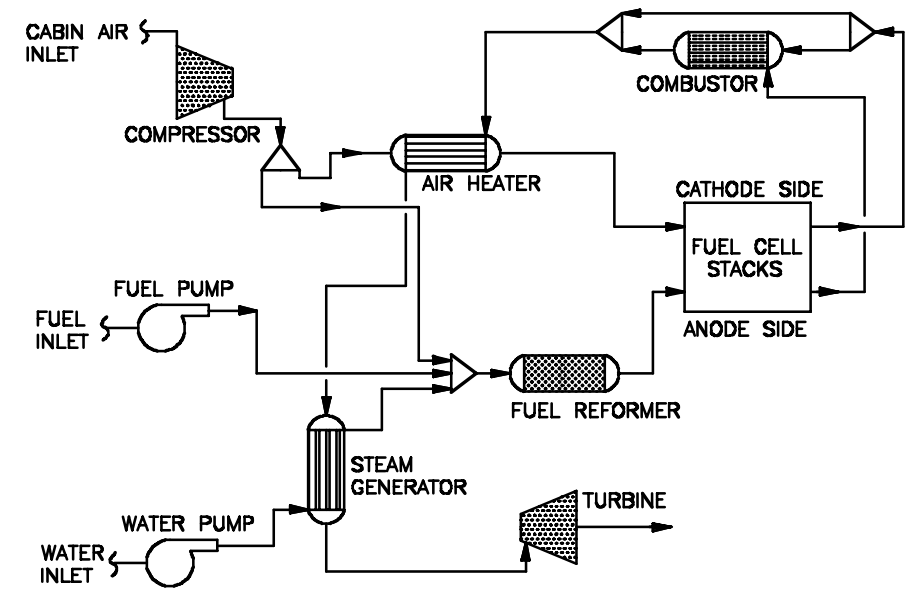

Figure 2.-Schematic of the SOFC/GT hybrid system. and volume of each of the pumps are considered in the system mass estimate, however. The air heat exchanger is a compact gas-gas crossflow heat exchanger and the steam generator is a multi-pass gas-liquid design. No recycling of either the anode or cathode streams is considered to simplify the initial studies and establish a baseline fuel cell system with which to compare more complex versions in the future.

As this is a system-level study, there are some simplifying assumptions to reduce the computational time required. All chemistry is assumed to be at equilibrium and the Chemical Equilibrium for Applications (CEA) code (ref. 10) is used for the calculations and related properties. The fuel cell model is zero-dimensional and based on the work of Hartvigsen et al. (ref. 11). This fuel cell model assumes that variation of performance with temperature and pressure is solely due to the Nernst equation. A constant ASR value is used and is assumed to be the dominant polarization term. The activation polarization is typically minimal for an SOFC and, for the operating voltages used in this application, the concentration polarization is small as well. The fuel cell is kept at a constant inlet temperature and while the exit temperature changes as a function of airflow and efficiency, the temperature averaged over the stack does not change enough to warrant a more detailed model. Similarly, the fuel cell inlet pressure variation is small enough that the dominant corresponding performance effect is from the Nernst equation. The turbomachinery is also zero-dimensional and based on non-isentropic theory. The heat exchangers are modeled using the compact heat exchanger methods from Kays and London (ref. 12). All components are considered adiabatic to the environment and a nominal pressure drop of 2 percent is included for the reformer and heat exchangers. The SOFC includes a 1.5 percent pressure drop. All models and results presented are at steady-state conditions.

The transition from design-point modeling to off-design performance modeling involves different approaches to some of the component models. For example, at the design condition, the fuel cell model sizes the required total active area to meet an input voltage and power requirement using the Nernst equation and an input stack-level area-specific resistance. At off-design conditions, this area is now fixed and the input power level governs the new operating voltage and current density. Similarly, the heat exchanger areas are sized at the design point using the required temperature changes, and at off-design, the performance is calculated at the same area. The compressor and turbine off-design performance is modeled using performance maps that correlate flow, pressure ratio, rotational speed, and efficiency. The maps used in this analysis are based on mean-line flow-path computational models underpinned by traditional empiricism. Finally, the nozzle area is sized at the design point and kept constant at off-design. If necessary, a variable-area nozzle is used, where the exhaust area is allowed to vary at off-design to match the turbine exit conditions.

The model is governed by several physical constraints that guide the system at both design and off-design conditions. First, the fuel cell temperature difference from inlet to exit is kept below $150 \mathrm{~K}$. This value is imposed by material constraints where the thermal expansion coefficients of the 
different cell materials may cause too much stress for the design. The SOFC is air-cooled and the airflow is increased if necessary to satisfy this requirement. The reformer chemistry is another important constraint that can cause coking if not met at all conditions. For this system, the molar atomic oxygen-tocarbon ratio $(\mathrm{O} / \mathrm{C})$ is kept at 0.95 and the molar steam-tocarbon ratio $\left(\mathrm{H}_{2} \mathrm{O} / \mathrm{C}\right)$ is kept at 0.70 . These values are based on prior analysis at NASA Glenn Research Center. From equilibrium calculations, the mixture provides a slightly exothermic reaction and is far from coke-producing chemistry that would foul the reformer and SOFC. The jet fuel is characterized as $\mathrm{C}_{12} \mathrm{H}_{23}$ with a lower heating value of $43.03 \mathrm{MJ} / \mathrm{kg}$, as specified in the CEA manuals (ref. 10). At the system level, this simplified jet fuel model compares well with more detailed models such as a multi-component hydrocarbon assay that characterizes a distillation curve (ref. 3). The $\mathrm{O} / \mathrm{C}$ ratio is met by varying the airflow split after the compressor. For an actual hardware system, it is assumed that a control valve would be used. The $\mathrm{H}_{2} \mathrm{O} / \mathrm{C}$ ratio is met by varying the water flow into the system. The combustor chemistry is also kept constant at stoichiometric conditions throughout the operating profile. This constraint is met by varying the postcathode flow split, again assuming a control valve.

\section{Results and Discussion}

\section{Full Power (440 kW) Analysis}

The original system design was at the cruise operational point and based on a net electrical power of $440 \mathrm{~kW}$. The configuration is shown in figure 2. The compressor pressure ratio and turbine expansion ratio, respectively 2.94 and 6, were chosen to maximize system efficiency while remaining within structural limits for single-stage radial designs. The fuel cell was sized based on this cruise condition and a cell voltage of $0.75 \mathrm{~V}$. A system thermal efficiency (LHV) of 56.1 percent was calculated. Further explanation of the system and all of the components can be found with (refs. 3 and 4).

The changes from cruise to sea level for the electrical power system are comparatively simple but are still very challenging for such a complex system. The compressor inlet pressure changes from 0.75 to 1 bar and the turbine exit pressure changes from 0.178 to 1 bar, at cruise and sea level, respectively. At sea level, the turbine cannot expand the gases nearly as much and for a constant power level, the fuel cell must produce more power as a result. The increase in fuel cell power implies an increase in fuel cell heat produced, even at constant or increasing fuel cell efficiency. With an air-cooled fuel cell, which is the standard for SOFC designs, more air must be sent to the fuel cell and therefore compressed as well. This creates a challenging thermodynamic system, where less available turbine power due to the higher ambient pressure implies more compressor power to supply a higher power fuel cell, which requires more turbine power to balance the compressor.

Since the sea level condition requires more airflow than cruise, that condition should be the 100 percent rotational speed design point rather than the original design in which the cruise condition sized the hardware. The cruise condition would therefore be run at a reduced speed and lower compressor pressure ratio, as shown in figures 3 to 6 . As a result, the fuel cell operates at a lower inlet pressure and therefore slightly reduced performance when compared to the original cruise design point system.

Another implication of the different air flow rates and fuel cell power levels between sea level and cruise is that the fuel cell inlet-exit temperature difference is actually less than the $150 \mathrm{~K}$ requirement described earlier. At the sea level design point, this $\Delta \mathrm{T}$ requirement sets the airflow. However, at cruise, the compressor/turbine balance sets the airflow, which is higher than necessary to cool the SOFC. This is a positive and conservative benefit in that a lower temperature gradient is better for the fuel cell material thermal stress profile.

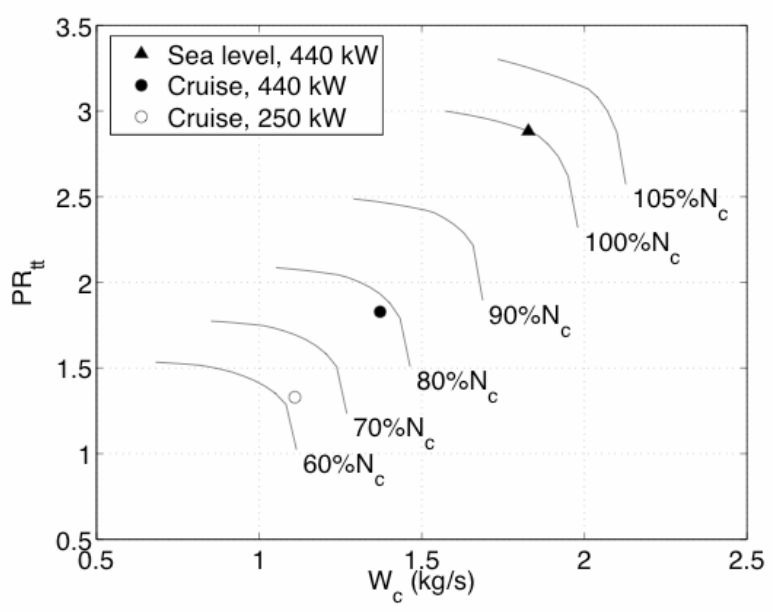

Figure 3.-Compressor map relating total-total pressure ratio, corrected flow, and corrected, non-dimensional shaft speed.

The sea level full power, cruise full power, and cruise part power operating points are plotted.

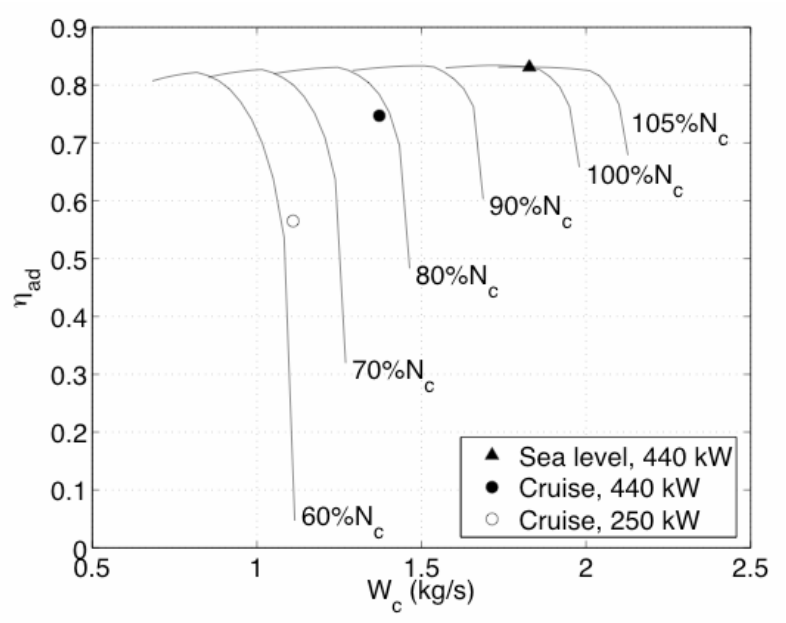

Figure 4.-Compressor map relating adiabatic efficiency, corrected flow, and corrected, non-dimensional shaft speed.

The sea level full power, cruise full power, and cruise part power operating points are plotted. 
The reduction in compressor pressure ratio at cruise also reduces the required turbine work to balance the cycle, counteracting the effect of the increased fuel cell cooling requirement described above. The turbine operation at the new rotational speed profile is acceptable in that the expansion ratio of 6 at cruise does not need to be at 100 percent speed due to the choked condition, seen in figure 5 . The sea level point is at a lower expansion ratio to account for the higher ambient pressure and the corrected flow is lower as a result. This may seem counterintuitive, as the compressor corrected flow increases from cruise to sea level. The reason is that while the actual flow rate increases from cruise to sea level, the turbine inlet pressure increases more than the square root of the turbine inlet temperature increases, resulting in a lower corrected flow rate for the turbine.

The fuel cell is sized at the highest required power condition (sea level $440 \mathrm{~kW}$ ). At the lower fuel cell power $440 \mathrm{~kW}$ cruise condition, the voltage increases and the current density decreases for a more efficient and lower heat-producing fuel cell. The two full-power operating points, along with the part power operating point described below, can be seen in figure 7. No polarization curve is shown because the temperature and pressure conditions change between sea level and cruise conditions. The $0.75 \mathrm{~V}$ operating point is now set by the sea level condition, and the cruise point results in a cell voltage of about $0.84 \mathrm{~V}$.

Finally, the nozzle was initially assumed to be a constant area convergent design for simplicity. However, due to the differences in operating points, a variable area nozzle is now used to balance the flow requirements. This will require further investigation in a transient and control environment. In addition, the integration of the compressor, turbine and nozzle system requires further engineering to ensure performance throughout the mission profile.

\section{Part Power (250 kW) Analysis}

The change from 440 to $250 \mathrm{~kW}$ at cruise is less challenging when compared to a change from cruise to sea level because the external pressure and temperature interfaces do not change. The fuel cell power requirement decreases along with the overall power requirement and because of the favorable exhaust pressure, the turbine is able to provide a substantial amount of excess power (about 33 percent of the net total). To meet the lower fuel cell power requirement, the voltage increases while the current density decreases, as shown in figure 7 . The higher voltage again implies an increased fuel cell efficiency and therefore reduced fuel cell cooling requirement. The airflow, as a result, is lower than the cruise full power level and the primary challenge is the balancing of the compressor and turbine at this airflow.

To reduce the airflow in the turbomachinery, the shaft speed is lowered beyond the cruise full power shaft speed. This also reduces the available compressor pressure ratio though there is still some flexibility in turbine expansion ratio due to the choking condition shown in figure 5. By maximizing the

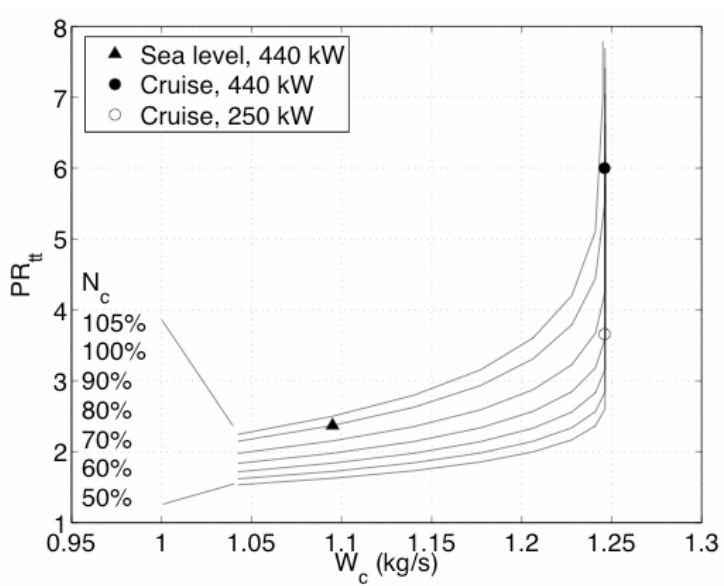

Figure 5.- Turbine map relating total-total expansion ratio, corrected flow, and non-dimensional corrected speed. The sea level full power, cruise full power, and cruise part power operating points are plotted.

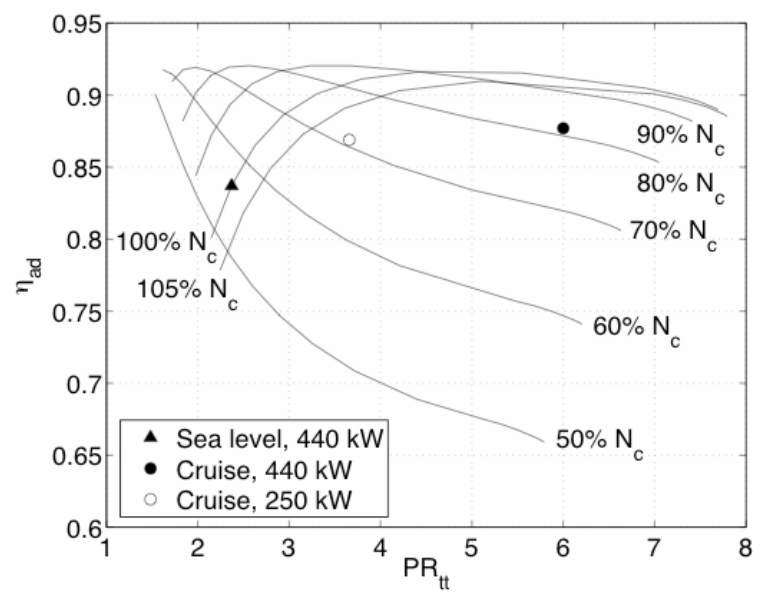

Figure 6.- Turbine map relating total-total expansion ratio, adiabatic efficiency, and non-dimensional corrected speed.

The sea level full power, cruise full power, and cruise part power operating points are plotted.

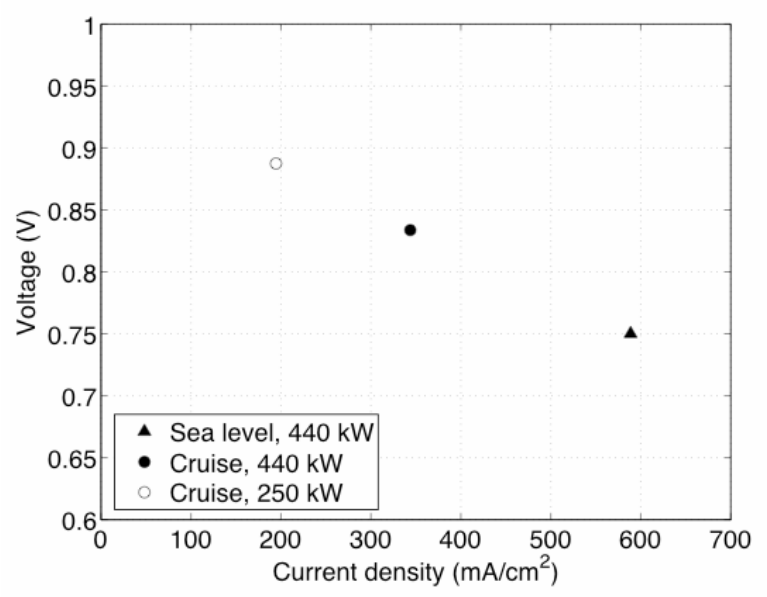

Figure 7.- SOFC sea level full power, cruise full power, and cruise part power operating voltage vs. current density. 


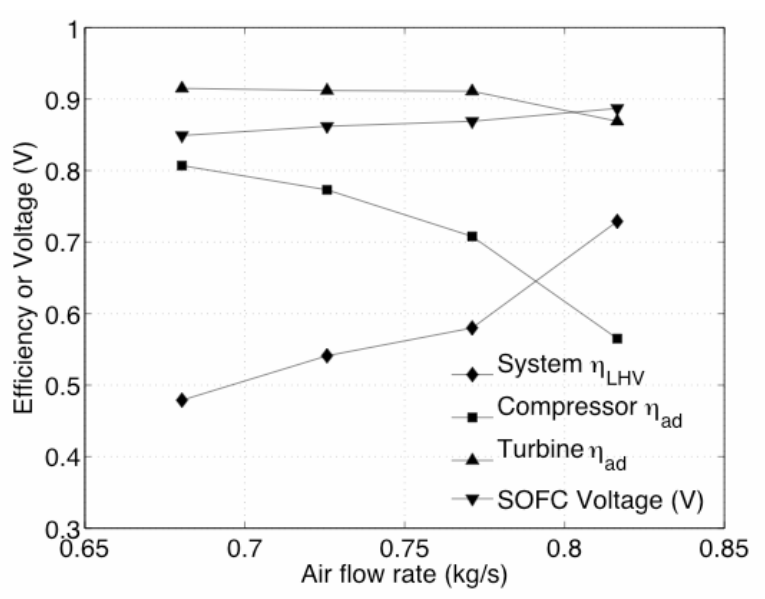

Figure 8.-Efficiency and voltage as a function of air flow rate for the cruise part power condition. The shaft speed is kept constant. The highest air flow rate shown is the point chosen for the other plots.

expansion ratio, the net generator electrical power is maximized and therefore the required fuel cell power is minimized. This is a positive effect on the system thermal efficiency, despite the more efficient fuel cell stack doing less work. This counterintuitive logic is due to the turbine taking advantage of the available pressure difference with the atmosphere. The fuel cell continues to increase efficiency with less power requirement so therefore the fuel flow rate actually decreases with increased turbine work.

Two independent variables are available to maximize the turbine expansion ratio: shaft speed and air flow rate. Figure 8 provides an example of varying air flow rate at a constant shaft speed and its effect on efficiencies and the fuel cell voltage. By increasing the air flow rate, the turbine is slowly increasing its expansion ratio (based on fig. 5) until the choking point near $0.8 \mathrm{~kg} / \mathrm{s}$ air flow rate. In the choking region, the expansion ratio increases more quickly and the system efficiency increases as a result. The expansion ratio increase is limited by the compressor efficiency, which decreases rapidly in this region, shown in figure 4. An interesting effect of this interaction is that both the compressor and turbine adiabatic efficiencies decrease as system thermal efficiency increases within this region. Since the system mass is constant at offdesign, system thermal efficiency is a likely primary figure of merit.

\section{System Summary}

A summary of the nodal data for each operating point is included in table 1. Some of the parameters listed describe the size rather than performance and therefore are constant throughout the operating conditions. An example of this is the fuel cell active area. This is sized at the design point (sea level full power) and is kept constant throughout the other two conditions.
The sizing of each of the components provides enough data to estimate a system level mass and volume. Parametric models were developed for this purpose and are described in detail in (ref. 4). The results show that the choice of design point has a substantial effect on the system mass. The original system, designed at cruise full power, has an estimated mass of $1396 \mathrm{~kg}$ while the system based on a sea level full power design point has an estimated mass of $1912 \mathrm{~kg}$. Most of the change is due to a larger fuel cell, which is required due to the larger power requirement from the fuel cell at sea level. For an aerospace application, this change has important implications for the feasibility of the overall system and its application.

With such a complex and interconnected system, there is most likely a better solution for operation of the system at all conditions. There are several independent variables that may improve the system including fuel cell anode utilization, fuel cell design voltage, system airflow, and rotational shaft speed. The anode utilization regulates the amount of unspent fuel that exits the anode of the fuel cell. This fuel is then reacted in the combustor to take advantage of its heat energy. The design point utilization (regardless of flight condition) is chosen at a maximum realistic value of 0.85 . Maximizing the fuel utilization makes the required fuel cell active area smaller, which can be directly correlated to fuel cell mass. From (ref. 4), the fuel cell mass is the single heaviest component in the overall system. As the utilization decreases, the combustor exit temperature increases, but the turbine inlet temperature does not increase by much due to the high amount of airflow required by the fuel cell. As a result, this variable is not very effective in balancing the system, although with a different configuration, it may be more useful. The fuel cell design voltage has a large impact of the size of the fuel cell stack as well. Based on an input area-specific resistance and fuel cell thermodynamic conditions, the Nernst voltage and resulting polarization curves are sized from the input design voltage. As the design voltage is decreased for the sea level design point, the required active area is reduced but the efficiency of the lower power cruise operating point is also reduced. The "best" design voltage for this system depends on the all of the operating points and their relative length of operation.

The system airflow and rotational shaft speed, described within the part power section as available independents, may also be effective for other off-design operating points, including the full power cruise point. The models show that multiple balanced solutions are available based on different air flow rate and shaft speed combinations. The selection is limited to viable operating points on each of the maps, but as seen in the part power case, optimizing the system operation for efficiency is possible and effective.

There are other approaches to balancing the system as well as other configurations that may reduce the size or even eliminate entire components. Further analysis of such a system would include an evaluation of the entire mission including ground operations. The figure of merit would be a combination of mass and efficiency, where in-flight efficiency is accounted for in terms of fuel and water mass saved. Finally, the idea of associating a design point with a certain operating point may no longer be necessary with more powerful computers and 
models. For example, the optimum fuel cell size may be somewhere between optimum for cruise and optimum for sea level. This again depends on the figures of merit and the specific mission. The migration towards multidisciplinary optimization is directly applicable to these systems and may prove in the future to be the best approach for complex hybrid systems design.

\section{Conclusions}

A systems-level model of a solid-oxide fuel cell/gas turbine hybrid bottoming cycle is analyzed and designed by evaluating the sea level and cruise full power operating points as well as a cruise part power operating point for a 300 passenger commercial aircraft electrical power unit. Each component within the system is sized to meet the $440 \mathrm{~kW}$ input electrical load at sea level full power. The cruise full power and cruise part power points are treated as off-design conditions. The discussion shows the risk in designing or judging a system based on just one operating point for a mission in which the ambient conditions are variable. While the system results are still promising, further gains can be made through continued analysis, system design, and optimization. In addition, more detailed analysis and hardware testing are necessary to account for such challenges as turbomachinery integration, transient operation, and localized chemical, thermal, and pressure gradients, all of which may also affect the final conclusions.

\section{References}

1. FAA Advisory Circular No. 120-42A, "Extended Range Operation with Two-Engine Airplanes (ETOPS)," Federal Aviation Administration, 1988.

2. Daggett, D., Freeh, J., Balan, C., Birmingham, D., "Fuel Cell APU for Commercial Aircraft," 2003 Fuel Cell Seminar Abstracts, Miami, FL, USA, 2003.

3. Steffen, C.J., Jr., Freeh, J.E., Larosiliere, L.M., "Solid Oxide Fuel Cell/Gas Turbine Hybrid Cycle Technology for Auxiliary Aerospace Power," ASME GT2005-68619, ASME Turbo Expo 2005, Reno, NV, USA, 2005.
4. Tornabene, R., Wang, X.Y., Steffen, C.J., Jr., Freeh, J.E., "Development of Parametric Mass and Volume Models for an Aerospace SOFC/Gas Turbine Hybrid System," ASME GT2005-68334, ASME Turbo Expo 2005, Reno, NV, USA, 2005.

5. Daggett, D., Eelman, S., and Kristiansson, G., "Fuel Cell APU for Commercial Aircraft," AIAA-2003-2660, AIAA International Air and Space Symposium and Exposition: The Next 100 Years, Dayton, OH, USA, 2003.

6. Magistri, L., Bozzolo, M., Tarnowski, O.C., Agnew, G.D., Massardo, A., "Design and Off-Design Analysis of a MW Hybrid System Based on Rolls-Royce Integrated Planar SOFC," ASME GT2003-38220, ASME Turbo Expo 2003, Atlanta, GA, USA, 2003.

7. Magistri, L., Ferrari, M.L., Traverso, A., Costamagna, P., Massardo, A.F., "Transient Analysis of Solid Oxide Fuel cell Hybrids, Part C: Whole-Cycle Model," ASME GT2004-53845, ASME Turbo Expo 2004, Vienna, Austria, 2004.

8. Roberts, R.A., Brouwer, J., Liese, E.A., Gemmen, R.S., "Dynamic Simulation of Carbonate Fuel Cell-Gas Turbine Hybrid Systems," ASME GT2004-53653, ASME Turbo Expo 2004, Vienna, Austria, 2004.

9. Kemm, M., Hildebrandt, A., Assadi, M., "Operation and Performance Limitations for Solid Oxide Fuel Cells and Gas Turbines in a Hybrid System," ASME GT200453898, ASME Turbo Expo 2004, Vienna, Austria, 2004.

10. Claus, R.W., McBride, B.J., Foster, R. "Application of a Chemical Equilibrium Analysis to In-Situ Lunar Resource Utilization," 1st AIAA Space Exploration Conference: Continuing the Voyage of Discovery, Orlando, FL, USA, 2005.

11. Hartvigsen, J., Khandkar, A., Elangovan, S., "Development of an SOFC Stack Performance Map for Natural Gas Operation," Proceedings of the Electrochemical Society, PV 99-19, Honolulu, HI, USA, 1999.

12. Kays, W.M. and London, A.L., Compact Heat Exchangers, 3rd ed., Kreiger Publishing Co., Florida, USA 1998. 
TABLE 1.-SEA LEVEL FULL POWER, CRUISE FULL POWER, AND CRUISE PART POWER SYSTEM RESULTS. THE PHYSICAL PARAMETERS, SUCH AS “ACTIVE AREA PER CELL"ARE CONSTANT FOR EACH CONDITION SINCE THE SYSTEM IS SIZED AT SEA LEVEL FULL POWER.

\begin{tabular}{|r|c|c|c|}
\cline { 2 - 4 } \multicolumn{1}{c|}{ System } & Sea Level, 440kW & Cruise, 440kW & Cruise, 250kW \\
\hline SOFC net electrical power & $429 \mathrm{~kW}$ & $279 \mathrm{~kW}$ & $168 \mathrm{~kW}$ \\
\hline Generator net electrical power & $11 \mathrm{~kW}$ & $161 \mathrm{~kW}$ & $82 \mathrm{~kW}$ \\
\hline Total net electrical power & $440 \mathrm{~kW}$ & $440 \mathrm{~kW}$ & $250 \mathrm{~kW}$ \\
\hline Fuel flow rate (Jet-A) & $0.0241 \mathrm{~kg} / \mathrm{s}$ & $0.0141 \mathrm{~kg} / \mathrm{s}$ & $0.00798 \mathrm{~kg} / \mathrm{s}$ \\
\hline Water flow rate & $0.0219 \mathrm{~kg} / \mathrm{s}$ & $0.0128 \mathrm{~kg} / \mathrm{s}$ & $0.00722 \mathrm{~kg} / \mathrm{s}$ \\
\hline Air flow rate & $1.81 \mathrm{~kg} / \mathrm{s}$ & $1.01 \mathrm{~kg} / \mathrm{s}$ & $0.816 \mathrm{~kg} / \mathrm{s}$ \\
\hline System thermal efficiency (LHV) & $42.4 \%$ & $72.6 \%$ & $72.8 \%$ \\
\hline Air preheater heat duty & $963 \mathrm{~kW}$ & $579 \mathrm{~kW}$ & $501 \mathrm{~kW}$ \\
\hline Steam generator heat duty & $57.0 \mathrm{~kW}$ & $33.3 \mathrm{~kW}$ & $18.8 \mathrm{~kW}$ \\
\hline
\end{tabular}

SOFC

\begin{tabular}{|r|c|c|c|}
\hline Active area per cell & $324 \mathrm{~cm}^{2}$ & Same as sea level & Same as sea level \\
\hline Average Nernst voltage & $0.985 \mathrm{~V}$ & $0.971 \mathrm{~V}$ & $0.965 \mathrm{~V}$ \\
\hline Cell voltage & $0.750 \mathrm{~V}$ & $0.834 \mathrm{~V}$ & $0.887 \mathrm{~V}$ \\
\hline Number of cells per stack & 149 & Same as sea level & Same as sea level \\
\hline Number of stacks & 20 & Same as sea level & Same as sea level \\
\hline Ideal stack voltage & $112 \mathrm{~V}$ & $124 \mathrm{~V}$ & $132 \mathrm{~V}$ \\
\hline Current density & $589 \mathrm{~mA} / \mathrm{cm}^{2}$ & $344 \mathrm{~mA} / \mathrm{cm}^{2}$ & $195 \mathrm{~mA} / \mathrm{cm}^{2}$ \\
\hline Inlet temperature & $700 \mathrm{C}$ & $700 \mathrm{C}$ & $700 \mathrm{C}$ \\
\hline Exit temperature & $850 \mathrm{C}$ & $837 \mathrm{C}$ & $788 \mathrm{C}$ \\
\hline Inlet pressure (cathode) & $2.86 \mathrm{bar}$ & $1.35 \mathrm{bar}$ & $0.979 \mathrm{bar}$ \\
\hline Exit pressure (cathode) & $2.82 \mathrm{bar}$ & $1.33 \mathrm{bar}$ & $0.964 \mathrm{bar}$ \\
\hline Specific power & $0.276 \mathrm{~kW} / \mathrm{kg}$ & $0.276 \mathrm{~kW} / \mathrm{kg}$ & $0.157 \mathrm{~kW} / \mathrm{kg}$ \\
\hline Power density & $1.11 \mathrm{~kW} / \mathrm{L}$ & $1.11 \mathrm{~kW} / \mathrm{L}$ & $0.632 \mathrm{~kW} / \mathrm{L}$ \\
\hline Anode utilization & $85.0 \%$ & $85.0 \%$ & $85.0 \%$ \\
\hline Cathode utilization & $9.55 \%$ & $10.10 \%$ & $6.83 \%$ \\
\hline
\end{tabular}

\section{Reformer}

\begin{tabular}{|r|c|c|c|}
\hline H2O/C ratio & 0.70 & 0.70 & 0.70 \\
\hline O/C ratio & 0.95 & 0.95 & 0.95 \\
\hline Exit temperature & $700 \mathrm{C}$ & $700 \mathrm{C}$ & $700 \mathrm{C}$ \\
\hline Inlet pressure & $2.86 \mathrm{bar}$ & $1.35 \mathrm{bar}$ & $0.979 \mathrm{bar}$ \\
\hline Exit pressure & $2.81 \mathrm{bar}$ & $1.32 \mathrm{bar}$ & $0.959 \mathrm{bar}$ \\
\hline Reactor exotherm & $31.4 \mathrm{~kW}$ & $4.16 \mathrm{~kW}$ & $-0.09 \mathrm{~kW}$ \\
\hline
\end{tabular}

\section{Compressor}

\begin{tabular}{|c|c|c|c|}
\hline Pressure ratio (total-total) & 2.88 & 1.83 & 1.33 \\
\hline Inlet temperature & $20 \mathrm{C}$ & $20 \mathrm{C}$ & $20 \mathrm{C}$ \\
\hline Exit temperature & $144 \mathrm{C}$ & $93.5 \mathrm{C}$ & $63.8 \mathrm{C}$ \\
\hline Adiabatic efficiency (total-total) & $83.1 \%$ & $74.7 \%$ & $56.5 \%$ \\
\hline \multicolumn{4}{|l|}{ Catalytic combustor } \\
\hline Inlet temperature & $850 \mathrm{C}$ & $837 \mathrm{C}$ & $788 \mathrm{C}$ \\
\hline Exit temperature & $1170 \mathrm{C}$ & $1156 \mathrm{C}$ & $1077 \mathrm{C}$ \\
\hline Estimated eq. ratio & 1.00 & 1.00 & 1.00 \\
\hline Inlet pressure & 2.76 bar & $1.30 \mathrm{bar}$ & $0.945 \mathrm{bar}$ \\
\hline Exit pressure & 2.76 bar & $1.30 \mathrm{bar}$ & $0.945 \mathrm{bar}$ \\
\hline
\end{tabular}

Turbine

\begin{tabular}{|r|c|c|c|}
\hline Expansion ratio (total-total) & 2.37 & 6.00 & 3.66 \\
\hline Inlet temperature & $412 \mathrm{C}$ & $359 \mathrm{C}$ & $246 \mathrm{C}$ \\
\hline Exit temperature & $294 \mathrm{C}$ & $145 \mathrm{C}$ & $110 \mathrm{C}$ \\
\hline Adiabatic efficiency (total-total) & $83.7 \%$ & $87.7 \%$ & $86.9 \%$ \\
\hline
\end{tabular}

\begin{tabular}{|c|c|c|c|}
\hline Exit areal & & & \\
\hline Exit static pressure & $1 \mathrm{bar}$ & 0.178 bar & 0.178 bar \\
\hline Pressure ratio (total-static) & 1.10 & 1.16 & 1.38 \\
\hline
\end{tabular}


Public reporting burden for this collection of information is estimated to average 1 hour per response, including the time for reviewing instructions, searching existing data sources, gathering and maintaining the data needed, and completing and reviewing the collection of information. Send comments regarding this burden estimate or any other aspect of this collection of information, including suggestions for reducing this burden, to Washington Headquarters Services, Directorate for Information Operations and Reports, 1215 Jefferson Davis Highway, Suite 1204, Arlington, VA 22202-4302, and to the Office of Management and Budget, Paperwork Reduction Project (0704-0188), Washington, DC 20503.

\begin{tabular}{|l|l|l|}
\hline 1. AGENCY USE ONLY (Leave blank) & $\begin{array}{c}\text { 2. REPORT DATE } \\
\text { December } 2005\end{array}$ & $\begin{array}{r}\text { 3. REPORT TYPE AND DATES COVERED } \\
\text { Technical Memorandum }\end{array}$
\end{tabular}

\section{TITLE AND SUBTITLE} 5. FUNDING NUMBERS

Off-Design Performance Analysis of a Solid-Oxide Fuel Cell/Gas Turbine Hybrid for Auxiliary Aerospace Power

6. AUTHOR(S)

Joshua E. Freeh, Christopher J. Steffen, Jr., and Louis M. Larosiliere

WBS-22-066-20-03

\section{PERFORMING ORGANIZATION NAME(S) AND ADDRESS(ES)}

National Aeronautics and Space Administration

John H. Glenn Research Center at Lewis Field

Cleveland, Ohio 44135-3191

8. PERFORMING ORGANIZATION REPORT NUMBER

E-15163

\section{SPONSORING/MONITORING AGENCY NAME(S) AND ADDRESS(ES)}

National Aeronautics and Space Administration

Washington, DC 20546-0001

10. SPONSORING/MONITORING AGENCY REPORT NUMBER

NASA TM-2005-213805

FUELCELL2005-74099

\section{SUPPLEMENTARY NOTES}

Prepared for the Third International Conference on Fuel Cell Science, Engineering, and Technology cosponsored by the ASME, ASME Nanotechnology Institute, Mechanical Engineering Magazine, RIT, NFCRC, Kettering University, SME, and Fuel Cell Markets, Ypsilanti, Michigan, May 23-25, 2005. Joshua E. Freeh and Christopher J. Steffen, Jr., NASA Glenn Research Center; and Louis M. Larosiliere, General Electric Gas Turbines, 300 Garlington Road, Greenville, South Carolina 29602. Responsible person, Joshua E. Freeh, organization code PBP, 216-433-5014.

12a. DISTRIBUTION/AVAILABILITY STATEMENT 12b. DISTRIBUTION CODE

Unclassified - Unlimited

Subject Category: 07

Available electronically at http://gltrs.grc.nasa.gov

This publication is available from the NASA Center for AeroSpace Information, 301-621-0390.

\section{ABSTRACT (Maximum 200 words)}

A solid-oxide fuel cell/gas turbine hybrid system for auxiliary aerospace power is analyzed using 0-D and 1-D system-level models. The system is designed to produce $440 \mathrm{~kW}$ of net electrical power, sized for a typical long-range 300-passenger civil airplane, at both sea level and cruise flight level $(12,500 \mathrm{~m})$. In addition, a part power level of $250 \mathrm{~kW}$ is analyzed at the cruise condition, a requirement of the operating power profile. The challenge of creating a balanced system for the three distinct conditions is presented, along with the compromises necessary for each case. A parametric analysis is described for the cruise part power operating point, in which the system efficiency is maximized by varying the air flow rate. The system is compared to an earlier version that was designed solely for cruise operation. The results show that it is necessary to size the turbomachinery, fuel cell, and heat exchangers at sea level full power rather than cruise full power. The resulting estimated mass of the system is $1912 \mathrm{~kg}$, which is significantly higher than the original cruise design point mass, $1396 \mathrm{~kg}$. The net thermal efficiencies with respect to the fuel LHV are calculated to be 42.4 percent at sea level full power, 72.6 percent at cruise full power, and 72.8 percent at cruise part power. The cruise conditions take advantage of pre-compressed air from the on-board Environmental Control System, which accounts for a portion of the unusually high thermal efficiency at those conditions. These results show that it is necessary to include several operating points in the overall assessment of an aircraft power system due to the variations throughout the operating profile.

\section{SUBJECT TERMS}

Solid oxide fuel cell; Simulation; Turbomachinery; Aircraft power supplies

15. NUMBER OF PAGES

14

16. PRICE CODE

20. LIMITATION OF ABSTRACT

\section{OF REPORT}

Unclassified

\section{SECURITY CLASSIFICATION OF THIS PAGE \\ Unclassified}

\section{SECURITY CLASSIFICATION OF ABSTRACT \\ Unclassified}



